İşletme Akademisi Dergisi
2021,2 (2): 176-185
DOl:10.26677/TR1010.2021.785
Dergi web sayfası: www.isakder.org

Derleme Makalesi

\title{
Serbest Meslek Kazançlarında Katma Değer Vergisi Sorunu
}

\author{
Öğr. Gör. Hasan KOÇYİĞİT \\ Kayseri Üniversitesi, Sosyal Bilimler Meslek Yüksekokulu, Kayseri, Türkiye. \\ hasankocyigit@kayseri.edu.tr, www.orcid.org/0000-0001-6461-2944.
}

\section{Kemal Cihangir AKBEY}

Yüksek Lisans Öğrencisi, Ankara Hacı Bayram Veli Üniversitesi Lisansüstü Eğitim Enstitüsü Sağlık Yönetimi Bölümü, Ankara, kemalcihangirakbey@gmail.com, www.orcid.org/0000-00022865-508X.

\section{$\ddot{O} z$}

Ülkemizde vergiyi doğuran olayın tespitinde, tahakkuk ve tahsil esası olmak üzere iki çeşit uygulama bulunmaktadır. Serbest meslek kazancının tarifi ve tespiti ilk olarak 1960 yılında yürürlüğe giren 193 Sayılı Gelir Vergisi Kanunu'nun 65. ve 67. maddelerinde açıklanmıştır. 1961 yılında yürürlüğe giren 213 Sayılı Vergi Usul Kanununun 236 ve 237. maddelerinde ise hangi hâllerde, ne için ve ne şekilde serbest meslek makbuzunun düzenleneceğinden bahsedilmiştir. Her iki kanunda da verginin doğabilmesi için tahsilât ve ödeme esası kabul edilmiştir. 1984 yılında yürürlüğe giren 3065 Sayılı Katma Değer Vergisi Kanunu, vergiyi doğuran olayı "mal teslimi ve hizmet ifası hâllerinde, malın teslimi veya hizmetin yapılması" halinde doğar şeklinde düzenlemiştir (KDVK m. 10/1-a). Yani önceki kanunlardan farklı olarak KDV Kanununda verginin doğması tahakkuk esasına bağlanmıştır. Kanunlar arasında ki bu çelişki serbest meslek kazancı sağlayan ve katma değer vergisi ödeyen binlerce kişiyi bilinmezlik içine sürüklemektedir. Bu çelişki serbest meslek erbaplarının idare ile sorunlar yaşamasına neden olmakta, idarenin ve bireylerin iş yüklerini artırmakta, tarafları bitmek bilmeyen uzun süren hukuksal mücadelelerin içerisine sokmaktadır. Bu makalede, uygulamada kargaşa yaratan "serbest meslek makbuzu" nun düzenleneceği zaman ve katma değer vergisinin ne zaman tahakkuk/tahsil edebileceği meselesi düzenlenmiştir. Ayrıca bu sorunun çözümüne ilişkin öneriler sunulmuştur.

Anahtar Kelimeler: Serbest meslek kazancı, serbest meslek makbuzu, katma değer vergisi, tahakkuk esası, tahsil esası.

Makale Gönderme Tarihi: 01.05.2021

Makale Kabul tarihi: 30.05.2021

\section{Önerilen Atıf:}

Koçyiğit, H., Akbey, K. C. (2021). Serbest Meslek Kazançlarında Katma Değer Vergisi Sorunu, İsletme Akademisi Dergisi, 2 (2): 176-185.

(C) 2021 İşletme Akademisi Dergisi. 


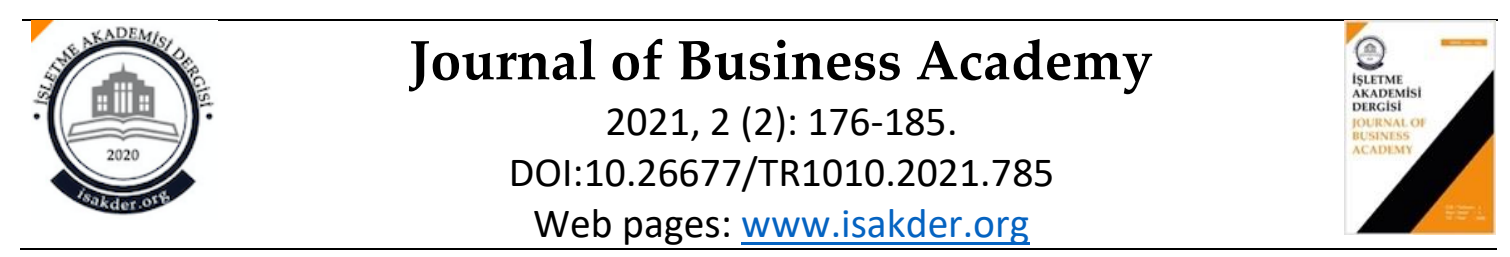

$\underline{\underline{\text { Review Article }}}$

\title{
Value Added Tax Problem of Self-Employment Incomes
}

\author{
Hasan KOÇYİĞİT \\ Kayseri University, Social Sciences Vocational School, Kayseri, Turkey. \\ hasankocyigit@kayseri.edu.tr, www.orcid.org/0000-0001-6461-2944.
}

\section{Kemal Cihangir AKBEY}

Ankara Hacı Bayram Veli University, Institute of Graduate Studies, Depatment of Health Management, Ankara, kemalcihangirakbey@gmail.com, www.orcid.org/0000-0002-2865-508X.

\begin{abstract}
There are two different practices for determination of activities on which taxes are imposed which are there alisation and there ceipt-based. Definition and identification of the self-employment income are explicitly specified in articles 65 and 67 of the Income Tax Law No.193 which was effectuated in 1960 for the first time. Although articles 236 and 237 of the Tax Procedure Law No.213 effectuated in 1961 specify the circumstances under which, for what and how a selfemployment voucher shall be made out, both laws stipulate that collection is based on receipt and payment. In the Value Added Tax No.3065 effectuated in 1984, on the other hand, the activity which will be subject totax is defined as "in cases of delivery of goods and services, the good should be delivered or the service should be provided" in Paragraph (a), Article 10 and attributed to the accrual basis. This caused an obscurity for thousands of people with regard to the Valued Added Tax imposed on self-employment incomes and led them to have problems with the administration. Along with the work loads of administration and individuals, then ever-ending legal process they have to be ar and related costs have further complicated the problem. In this article, some suggestion sare made with regard to making out self-employment vou chers arising disputes in practice and the solution to the problem of accrued Value Added Tax.
\end{abstract}

Keywords: Self-employment income, self-employment voucher, value added tax.

Received: 01.05.2021

Accepted: 30.05 .2021

\section{Suggested Citation:}

Koçyiğit, H., Akbey, K. C. (2021). Value Added Tax Problem Of Self-Employment Incomes, Journal of Business Academy, 2 (2): 176-185.

(C) 2021 Journal of Business Academy. 


\section{GİRIŞ}

"Serbest meslek faaliyetini kendi nam ve hesabına, mutat meslek halinde ifa eden; avukat, doktor, diş hekimi, veteriner hekim, mimar, mühendis, müşavir, serbest muhasebeci mali müşavir, yeminli mali müşavir, danışman, ressam, yazar, bestekar, kimyager, noter, öğretmen, artist, menajer, senarist, yönetmen, ebe, sünnetçi, arzuhalci, rehber ve sağllk memuru gibi kişiler serbest meslek erbabıdır" (www.gib.gov.tr). Serbest meslek makbuzu; serbest meslek erbabı tarafından mesleki faaliyetleri ile ilgili her türlü tahsilât için düzenlenin. Mesleki faaliyetler karşılığı alınan ücretlerin tahsil edildiğini gösteren bir belgedir. Serbest meslek makbuzu, serbest meslek kazancı elde edenler tarafından düzenlenir ve fatura hükmündedir (www.megep.meb.gov.tr). Vergilemede, ilgili gelirin tespitinde tahakkuk ve tahsil esası kabul edilmektedir. Vergi literatüründe bu kavramlar çok kullanılmaktadır. Tahakkuk esasında; gelir veya giderin mahiyet veya tutar olarak kesinleşmiş olması yani geliri veya gideri doğuran işlemin eksiksiz tekemmül etmesi, bunun yanı sıra miktarın ve işlemden kaynaklanan alacak veya borcun ödeme şartlarının da belirlenmiş olması yeterlidir (Yıldız, 2015: 202). Kazancın tespit edilmesinde ödemenin veya tahsilatın yapılmış olması şartı yoktur. Yani gelir unsurlarının veya gider unsurlarının doğması için tahsilâtın veya ödemenin yapılmış olması şartı bulunmamaktadır. Gelir ve giderin hesabında bedeli ödenmeyen bu işlem dikkate alınır. Tahsil esasında ise; kazancın tespit edilmesinde tahsil edilmiş gelirler dikkate alınmaktadır. Serbest meslek kazançlarının vergilendirilmesinde tahsil esası geçerlidir. Tahsilat esasında; bir hizmetin verilmiş ve tamamlanmış olması, söz konusu hizmetin karşılığı tahsil edilmediği sürece bunun gelir olarak dikkate alınmasını gerektirmez (www.vergidosyasi.com).

$\mathrm{Bu}$ çalışmanın amacına yönelik olarak serbest meslek erbapları tarafından verilen hizmetler incelendiğinde; verilen hizmetlerin mütemadi olarak devam ettiği, mal satımlarında olduğu gibi bir anda gerçekleşmediği görülmektedir. Yani verilen hizmetler bir anda gerçekleşmemekte süreklilik arz etmektedir. Örneğin; bir aylık, bir yıllık, beş yıllık gibi belirli dönemlere yayılmaktadır. Bununla birlikte KDV Kanununa göre "hizmet gerçekleşmiştir, bu nedenle serbest meslek kazançlarında KDV'yi doğuran olay meydana gelmiştir, o halde KDV tahakkuk etmelidir" demek tahsil edilememiş ücretlerin vergisini ödeme sonucunu doğurabilmektedir.

Serbest meslek kazancının tarifi ve kazancın nasıl tespit edileceği 1960 yılında yürürlüğe giren 193 Sayılı Gelir Vergisi Kanununda düzenlenmiştir (GVK m. 65. ve 67). 1961 yılında yürürlüğe giren 213 Sayılı Vergi Usul Kanunu'nda ise serbest meslek makbuzlarının meslek erbapları tarafından ne zaman ve nasıl düzenleneceğine ilişkin hükümler getirilmiştir (VUK m. 236. ve 237). Her iki kanunda makbuzun düzenlenmesi için tahsilât yapılmış olma esasını aramaktadır.

1984 yılında yürürlüğe giren 3065 Sayılı Katma Değer Vergisi Kanunu vergiyi doğuran olayı yani serbest meslek makbuzu düzenlenmesi gereken zamanı farklı şekilde düzenlemiştir. Bu kanun; "mal teslimi ve hizmet ifası hallerinde, malın teslimi veya hizmetin yapılması", "kısım kısım mal teslimi veya hizmet yapılması mutad olan veya bu hususlarda mutabık kalınan hâllerde, her bir kısmın teslimi veya bir kısım hizmetin yapılması" anında meydana gelir şeklinde düzenlemiştir (KDVK $\mathrm{m} \cdot 10 / 1-\mathrm{a}, \mathrm{c})$.

Serbest meslek erbabı tarafından görülen hizmetler yukarıda da değinildiği gibi çoğu zaman bir "süreç" içermektedir. Serbest meslek erbabı tarafından hizmet bir bütün halinde sürdürülecek yani kısımlara ayrılmayacaksa "a" fikrası, hizmet kısımlara ayrılarak ifa edilecekse " $c$ " fikrası kapsamında değerlendirme yapılabilecektir.

Bu bağlamda bu çalışmanın amacı; Serbest meslek kazançlarında KDV yönünden vergiyi doğuran olayın zamanının netleştirilmesi, bu belirsizlikten dolayı oluşan kargaşanın ortadan kaldırılması, serbest meslek mensuplarının daha huzurlu bir şekilde mesleki faaliyetlerini icra 
etmelerini sağlamaya yardımcı olmaktır. Bu çelişkinin düzeltilmesi ile idarenin kurumlarında yaratılan gereksiz iş yoğunluğunun azalacağı da düşünülmektedir.

\section{HUKUKSAL BOYUTU}

31/12/1960 tarihinde yürürlüğe giren 193 Sayılı Gelir Vergisi Kanunu, 04/01/1961 tarihinde yürürlüğe giren 213 Sayılı Vergi Usul Kanunu ve 25/10/1984 tarihinde yürürlüğge giren 3065 Sayılı Katma Değer Vergisi Kanunu çalışmanın hukuksal boyutunu oluşturmaktadır.

\subsection{Katma Değer Vergisi Kanunu}

3065 sayılı Katma Değer Vergisi Kanunu'nun 10. maddesinde vergiyi doğuran olayın nasıl meydana geldiği, "Vergiyi Doğuran Olay" başlığı altında belirtilmiştir. Buna göre vergiyi doğuran olay:

“a) Mal teslimi ve hizmet ifası hallerinde, maln teslimi veya hizmetin yapılmasl,

b)Malın tesliminden veya hizmetin yapılmasından önce fatura veya benzeri belgeler verilmesi hallerinde, bu belgelerde gösterilen miktarla sinırl olmak üzere fatura veya benzeri belgelerin düzenlenmesi,

c) Kısım kısım mal teslimi veya hizmet yapılması mutat olan veya bu hususlarda mutabık kalınan hallerde, her bir kısmin teslimi veya bir klsim hizmetin yapılmasi durumunda meydana gelir" (www.mevzuat.gov.tr) şeklinde düzenlenmiştir.

\subsection{Gelir Vergisi Kanunu Ve Vergi Usul Kanununda Serbest Meslek Kazançları}

\subsubsection{Gelir Vergisi Kanunu}

Gelir Vergisi Kanununda serbest meslek kazancının tarifi yapılmıştır. Buna göre; "Her türlü serbest meslek faaliyetinden doğan kazançlar serbest meslek kazancıdır. Serbest meslek faaliyeti; sermayeden ziyade şahsi mesaiye ilmi veya mesleki bilgiye veya ihtisasa dayanan ve ticari mahiyette olmayan işlerin işverene tabi olmaksızın şahsi sorumluluk altında kendi nam ve hesabına yapılmasıdır. Tahkim işleri dolayısıyla hakemlerin aldiklarn ücretler ile kolektif, adi komandit ve adi şirketler tarafindan yapılan serbest meslek faaliyeti neticesinde doğan kazançlarda serbest meslek kazancıdır" (GVK m. 65).

Gelir Vergisi Kanununda serbest meslek kazancının nasıl tespit edileceği açılanmıştır. Buna göre; “Serbest meslek kazancı bir hesap dönemi içinde serbest meslek faaliyeti karşılığı olarak tahsil edilen para ve ayınlar ve diğer suretlerle sağlanan ve para ile temsil edilebilen menfaatlerden bu faaliyet dolayısıyla yapılan giderler indirildikten sonra kalan farktır. Müşteri veya müvekkilinden, serbest meslek faaliyeti ile ilgili olmak üzere para ve ayın şeklinde alınan gider karşıllkları kazanca ilave edilir" şeklinde düzenlenmiştir (GVK m. 67) (www.mevzuat.gov.tr).

\subsubsection{Vergi Usul Kanunu}

213 Sayılı Vergi Usul Kanununda hangi hâllerde ve ne şekilde serbest meslek makbuzu düzenleneceği belirtilmiştir. Buna göre:

"Serbest meslek erbabının mesleki faaliyetlerine ilişkin her türlü tahsilatı için iki nüsha serbest meslek makbuzu tanzim etmek ve bir nüshasın müşteriye vermek, müşteri de bu makbuzu istemek ve almak mecburiyetindedir" (VUK m. 236).

"Serbest meslek makbuzlarma:

1. Makbuzu verenin soyadı adı veya unvanı, adresi, vergi dairesi ve hesap numarast,

2. Müşterinin soyadı, adı veya unvanı ve adresi, 


\section{Alınan paranin miktarı,}

\section{Paranın alındığ tarih,}

yazllır ve bu makbuzlar serbest meslek erbabı tarafindan imzalanır. Serbest meslek makbuzları seri ve sira numarası dâhilinde teselsül ettirilir" şeklinde düzenlenmiştir (VUK m. 237) (www.mevzuat.gov.tr).

\section{SERBEST MESLEK KAZANÇLARINDA KATMA DEĞER VERGİSINE İLIŞKINN LİTERATÜR TARAMASI}

Serbest meslek kazançlarının KDV'sine ilişkin literatür araştırıldığında mukteza (özelge), makale ve Danıştay kararlarına rastlanılmıştır.

1) Denizli Vergi Dairesi Başkanlı̆̆1 Mükellef Hizmetleri Grup Müdürlüğü'nce düzenlenen “Mukteza"da özetle: (Say1: B.07.1.GïB.4.20.15.01-30-MUK-2010-54-203 - 20/07/2011)

-Katma değer vergisi bakımından vergiyi doğuran olay malın teslimi veya hizmetin ifasına bağh olduğundan, serbest meslek faaliyetine ilișkin kazancm tahsil edilmediği durumlarda düzenlenecek serbest meslek makbuzunda, sadece KDV tutarnna yer verilerek "........TL mal teslimine / hizmet yapulmasına ilișkin olup bedeli tahsil edilmemiștir." şeklinde not yazılması,

-Serbest meslek kazancında tahsil esast geçerli olduğundan (kazancın kısım kısım tahsil edildiğ i durumlar dahil) serbest meslek makbuzunun tahsil edilen tutar kadar düzenlenmesi ve makbuz üzerinde "KDV için ....... gün ve........ saynl serbest meslek makbuzu düzenlenmiștir." şeklinde not yazılması gerektiğ (www.gib.gov.tr) düzenlenmiştir.

2) Çanakkale (2008) tarafından yapılan "Serbest Meslek Kazançlarında Tahsilat Olmasa da KDV Doğar" isimli çalışmada;

“Hukukta genel geçer sayılan kurala göre; özel kanun hükmünün her zaman genel kanun hükmünün önüne geçeceği, bu kapsamda 213 Sayılı Vergi Usul Kanununun, Katma Değer Vergisi Kanununa göre genel kanun sayılacağı ve özel kanun sayılan KDV kanununun uygulanması gerektiği,

Serbest meslek makbuzunun adı üstünde bir makbuz olduğu, bu makbuzun düzenlenme kaidesinin katma değer vergisinin tahakkuku ile ilgisiz olduğu, yine Gelir Vergisi Kanunu'nun serbest meslek kazançları için öngördüğü tahsil esasının sadece Gelir Vergisi Kanununu bağlayacă̆ı,

Tamamen kendine özgü hükümleri ve usulü bulunan Katma Değer Vergisi Kanununa göre serbest meslek faaliyetinin bir hizmet olduğu, bu hizmetin ifası durumunda verginin doğmuş olacağı, bunun için hizmetin karşıllı̆̆ paranın tahsil edilmesinin ve makbuz düzenlenmesinin KDV açısından hiçbir öneminin bulunmayacağı, hizmet ifasından çok sonra tahsilat yapılmış olsa bile katma değer vergisinin, hizmetin ifa edildiği KDV vergilendirme döneminde hesaplanarak beyan edilmesi gerektiği,

Gelir Vergisi Kanunu (1960) ve Vergi Usul Kanununda (1961) tahsil esasının kabul edilmesinin, kanunların yakın tarihlerde kabul edilmesinin bir sonucu olduğu, Katma Değer Vergisi Kanununun çok sonraları (1984)kabul edildiği için farklı bir sistematiğinin olduğu, kanunlardaki farklılığın, kanunların koyuldukları dönemlerdeki vergi mantığındaki farklılıktan kaynaklandığı,

KDV Kanunu hükümlerinin çok açlk olduğu, serbest meslek mensuplarının hizmeti ifa ettiklerinde tahsilât yapmamış olsalar dahi hizmetin karşılığı olan bedeli KDV 
beyanlarında dikkate almak durumunda oldukları (www.muhasebenet.net) belirtilmiştir.

3)Danıştay 9. Dairesinin resen tarh edilen Katma Değer Vergisi ile ilgili 19.02.1998 tarihinde 1997/402 esas ve 1998/651 sayılı kararında:

Mal Müdürlüğü tarafından resen tarh edilen Katma Değer Vergisine, serbest muhasebecilik ve mali müşavirlik faaliyetiyle uğraşan davacının Çorum Vergi Mahkemesinde dava açtığı, mahkemenin 31.10.1996 tarih ve 1996/519 sayılı kararı ile davacı lehine karar verdiği,

Mal müdürlüğü tarafından vergi mahkemesi kararının temyiz edildiği; “KDV'nin resen tarhiyata konu olduğu, davacının 1994 yılında elde ettiği serbest meslek kazancına ait beyannamelerini Ocak, Şubat, Mart, Nisan, Mayıs, Haziran, Temmuz, Ağustos, Eylül, Ekim, Kasım dönemlerinde matrahsız olarak verdiği, tamamını ise aynı yılın Aralık ayında beyan etmesi nedeniyle takdir komisyonu kararına dayanılarak yıl içinde elde edilen hasılatın 12 aya bölünmesi suretiyle belirlenen matrah üzerinden uyuşmazlık konusu tarhiyatın yapıldığı, davacının müşterilerden tahsil ettiği ücretin aylık ya da üçer aylık olarak tahsil edildiğine ilişkin herhangi bir somut saptama yapılmadığı gibi ücret gelirlerinin de 30.12.1994 tarihinde tahsil edildiğinin anlaşıldığı, temyiz konusu, katma değer vergisi beyannamelerinin matrahsız olarak verildiği, yükümlünün serbest meslek faaliyetini aylık ücret tarife protokolüne göre yaptığı, ücretin Aralık ayında alınacağına ilişkin bir hüküm bulunmadığı, bu nedenle bozulmasını talep ettiklerini, Danıştay'ın Çorum Vergi Mahkemesinin kararında, 2577 sayılı İdari Yargılama Usulü Kanununun 49. maddesinin 1. fikrasında sayılan bozma nedenlerinden hiçbirisi bulunmadığ gerekçesiyle temyiz isteminin reddine, anılan mahkeme kararının onanmasına 19.02.1998 tarihinde oybirliği ile karar verdiği (www.emsal.danistay.uyap.gov.tr) belirtmektedir.

4)Danıştay Vergi Dava Daireleri Kurulu'nun 14.4.2006 gün ve 2006/19 (E), 2006/92 (K) sayılı kararında:

Tekirdağ Vergi Mahkemesinin 14.11.2000 gün ve 2000/168 ( E ), 2000297 (K) sayılı kararına konu olayda; "Serbest muhasebecilik yapan davacının, 1998 yılında 46 adet mükellefine hizmet ifasında bulunduğu, bazı mükelleflerinden tahsil etmesi gereken ücreti ise 1999 yılında tahsil ettiği, bu nedenle serbest meslek makbuzunu, hizmetin ifa edildiği 1998 yıllı yerine ücretin tahsil edildiği 1999 yılında düzenlediği ve katma değer vergisi beyanına konu ettiğini,

Tekirdağ Vergi Dairesi Müdürlüğü'nün hasılatın bir kısmını serbest meslek makbuzu düzenlenemeyerek kayıt dışı bırakan muhasebeciye Katma Değer vergisi cezası saldığı, Davacı serbest muhasebecinin talebi üzerine Tekirdağ Vergi Mahkemesinde, salınan cezanın iptali için dava açıldığı, mahkemenin; 'serbest meslek faaliyetinde vergiyi doğuran olay, verilen hizmet karşılığında kısmen veya tamamen ücretin tahsil edilmesiyle meydana gelir' gerekçesiyle kesilen cezayı iptal ettiği,

İlk derece mahkemesinin kararının idare tarafından temyiz edildiği, Danıştay 7. Dairesinin 2001/765 ( E ) ve 2004/791 (K) ve 31.03.2004 tarihli kararında; "katma değer vergisi açısından vergiyi doğuran olay, 3065 sayılı Katma Değer Vergisi Kanununun 10'ncu maddesine göre; malın teslimi veya hizmetin yapılması anında meyana geldiği, bu hususta ticari, sınai, zirai veya serbest meslek faaliyetleri çerçevesinde yapılan teslim ve hizmetler yönünden farklı bir düzenlemeye yer verilmediği, serbest meslek kazancının tespitinde, gelir vergisi açısından, tahsilat esasının getirilmiş olmasının da bu durumu değiştirmeyeceği, bu nedenle vergiyi doğuran olaya, hizmetin yapıldığı tarihe 
göre değil de tahsilatın yapıldığı tarihe göre karar veren mahkemenin kararının bozulması gerektiği,

İlk derece mahkemesinin, Danıştay 7. Dairesinin bozma kararına direnmesi üzerine karar ilgili vergi dairesi tarafından yeniden temyiz edilmiş, temyiz üzerine Danıştay Vergi Dava Daireleri Kurulu, 2006/19 (E ), 2006/92 (K) ve 14.4.2006 tarihli kararı ile; “Uyuşmazlığın çözümü, serbest meslek faaliyetinde, katma değer vergisi açısından, vergiyi doğuran olayın meydana geldiği tarihin tespitine bağlı bulunduğu, katma değer vergisi açısından vergiyi doğuran olayın malın teslimi veya hizmetin yapılması anında meydana geldiği, ticari, sınai, zirai veya serbest meslek faaliyeti çerçevesinde, yapılan teslim veya hizmetler yönünden farklı bir düzenlemeye yer verilmediği, serbest meslek kazancının tespitinde, gelir vergisi açısından tahsilat esasının getirilmiş olmasının da belirtilen hukuki durumu değiştirmeyeceği, bu bakımdan, dava hakkında serbest muhasebecilik faaliyetinde verilen hizmetin yapıldığı tarihin araştırılması ve vergiyi doğuran olayın, hizmetin yapıldığı tarihte meydana geldiği hususunun gözetilmesi suretiyle yapılacak yargılamayla ulaşılacak sonuca göre karar verilmesi gerektiği, ilk derece mahkemesinin temyize konu kararında ssrar etmesinde isabet görülmediği" şeklindedir.

\section{SONUÇ ve ÖNERİLER}

Yukarıda 1 no'lu bölümde bahsi geçen mukteza (özelge) ile ilgili olarak: 213 Sayılı Vergi Usul Kanunun 236.ve 237. maddelerinde serbest meslek makbuzlarının ne için ve ne şekilde düzenleneceği açıkça düzenlenmiştir. Tahsilât gerçekleştiğinde serbest makbuzu düzenlenecektir. Buna rağmen ilgili kanun maddeleri göz ardı edilerek, tahsilât olmadığı halde serbest meslek makbuzu düzenlenmesini zorunlu kılan muktezaya ilişkin görüş açıkça ilgili kanun maddelerine aykırıdır.

Muktezada (özelge) bahsedilen serbest meslek makbuzu düzenlenmesini hizmetin ifa edilmesine bağlayabilmek teknik olarak da çok mümkün değildir. Serbest meslek erbaplarının faaliyetleri anlık yapılıp biten ve bir anda sonlanan hizmetler değildir. Faaliyetler çoğunlukla bir süreç dâhilinde bütünlük arz ederek devam etmektedir. Serbest meslek erbaplarından olan mali müşavirler veya avukatlar müvekkil/mükellefleri ile yaptıkları hizmet sözleşmelerinde bir süreç belirtmek zorunda değildir. Ayrıca bu hizmetin ne kadar sürebileceğini sözleşmede gösterip göstermeme konusunda mevzuatta bir düzenleme veya sinırlama da yoktur. Avukatlar, avukatlık sözleşmelerinde verilen hizmeti; "sadece dava dosyasının açılmış olması", "davanın kazanılmış ya da kaybedilmiş olması", "üst mahkemelere başvurulmuş olması", "bir saatlik danışmanlık hizmetinin sağlanması" gibi şekillerde göstermezler. Örneğin avukatla müvekkili kendi arasında, "ağır ceza mahkemesinin görevine giren soruşturma ve kovuşturmanın sonuna kadar devam edecek sürede müdafilik hizmeti sunumu yapılacaktır" şeklinde anlaşırlar. Avukatlık sözleşmelerinde hizmetin ne kadar süreceği çoğu zaman yargı mercilerinin performansına da bağlı olmaktadır. O halde verilen hizmet örnek verilen bu sektörlerde bir zamana yayılmaktadır. Hizmetin ifası bir anda gerçekleşmemektedir. Bu nedenle serbest meslek erbaplarının hizmetleri net bir tarihe dayandırılamaz. Bundan dolayıdır ki hizmet ifası tamamen gerçekleşmiş ve KDV'yi doğuran olay tam olarak vuku bulmuştur demek 213 Sayılı VUK 236. ve 237. maddelerine ve 193 Sayılı GVK 65. ve 67. maddelerine aykırılık teşkil etmektedir. Bu nedenle bahse konu özelge'de hizmetin ifa edilmesi üzerine, serbest meslek erbabını tahsilat gerçekleşmeden serbest meslek makbuzu düzenlemek zorunda bırakmak KDV Kanununa uygun olarak değerlendirilebilirse de açıkça VUK ve GVK'na aykırılık teşkil etmektedir. 
Yukarıda 2 no'lu bölümde bahsi geçen; “Serbest Meslek Kazançlarında Tahsilat Olmasa da KDV Doğar' çalışmasıyla ilgili olarak: Serbest meslek makbuzu, serbest meslek mensuplarının gelir vesikalarıdır. Üzerinde vergi tutarlarının beyan edildiği bir değerli belgenin sadece basit bir makbuz olarak görülmesi ve bu doğrultuda diğer kanunlardaki açık düzenlemeleri dikkate almadan sadece KDV Kanununa göre yorum yapılmasını hukuki ve doğru bulmuyoruz. Osman F. Çanakkale, 2008 yılındaki 'Serbest Meslek Kazançlarında Tahsilat Olmasa da KDV Doğar' adlı çalışmasında; Katma Değer Vergisi Kanununun farklı bir mantık çerçevesinde hazırlandığını söylemektedir. Ancak farklı bir mantık dâhilinde de olsa kanun maddesi yorumlanırken vergiye ilişkin temel kanunlar dikkate alınmadan yorumlanması yorumcuyu farklı sonuçlara götürür. $\mathrm{Bu}$ yorumun doğru bir yorum olabilmesi için bir bütün halinde yapılması gerekir. Ayrıca bu kapsamda serbest meslek mensupları; "hizmeti ifa ettiklerinde tahsilat yapmamış olsalar dahi hizmetin karşıllı̆̆ olan bedeli, serbest meslek makbuzu düzenledikleri için KDV beyanlarında dikkate almak zorundadır" şeklinde beyan etmiştir. Ancak; ilk olarak hizmetin ifası tam olarak gerçekleşmemekle birlikte, bir ödeme ve tahsilât yok iken bundan bahsedilmemesi gerektiği söylenebilir.

Serbest meslek makbuzu, serbest meslek mensuplarının gelir vesikalarıdır. 193 Sayılı Gelir Vergisi Kanunu ve 213 Sayılı Vergi Usul Kanununda serbest meslek makbuzlarının hangi durumlar dâhilinde düzenleneceği çok açık şekilde belirtilmiştir. Bu kanunlara tezatlık yaratacak şekilde serbest meslek makbuzu düzenleneceğini söylemek yasaya aykırılık göstermekten başka bir şey değildir.

Yukarıda 3 no'lu bölümde bahsi geçen; Danıştay 9.Dairesinin resen tarh edilen Katma Değer Vergisi ile ilgili 19.02.1998 tarihinde 1997/402 esas ve 1998/651 sayılı kararından da anlaşıldığı üzere verilen hizmetlerin karşılı̆̆ını teşkil eden bedelin hangi tarihte tahsil edildiği ve serbest meslek makbuzunun da tahsilatla birlikte düzenlenmiş olduğu tarihte Katma Değer Vergisi beyanına matrah teşkil edeceği belirtilmiştir. Tahsilat esasını dikkate alan Danıştay 9. Daire kararının 213 ve 193 sayılı Kanunlara uygun olduğu değerlendirilmektedir.

Yukarıda 4 no'lu bölümde bahsi geçen; Danıştay Vergi Dava daireleri kurulunun 14.04.2006 gün ve 2006/19 sayılı kararının daha akıllıca etüd edilebilmesi için; öncelikle serbest meslek mensupları tarafından ifa edilen hizmetlere ilişkin sözleşmelerin bilinmesi gerekir. Kararda bahsi geçen serbest muhasebeci mali müşavirler, uygulamada mükelleflerle sözleşme yaparken çoğunlukla sözleşmelerini 1 yıllık yaparlar. Fakat mevzuatta hizmet sözleşmesinin süresine ilişkin bir kısıtlama gösterilmemiştir. Örneğin bir serbest muhasebeci mali müşavir 10 yıllık bir hizmet sözleşmesi yapabilir. Bu sözleşmede ücretin hangi zamanda ve nasıl tahsil edileceği açıkça gösterilmesi zorunlu değildir. Yani hizmet alanla, serbest muhasebeci mali müşavir 3 er aylık periyotlarla tahsilat yapılacağını veya 10 yıllık hizmetin tamamlanması ile tahsilatın yapılabileceğini kararlaştırabilirler. Son ihtimalde 10. yılın sonunda hizmetin tamamlanması ve tahsilatın yapılmasıyla 213 ve 193 sayılı kanunlara göre serbest meslek makbuzu düzenlenmesi zorunludur. Tahsilatı yapan serbest muhasebeci mali müşavir 3065 sayılı Katma Değer Vergisi Kanununa göre hizmetin tamamlandığı ayı takip eden ay içerisinde 10 yıllık hizmet bedelini katma değer vergisi beyannamesine yansıtacaktır. Fakat 10. yılın sonunda hizmet bedelini tahsil edemeyen serbest muhasebeci mali müşavir 213 ve 193 sayılı kanunlara göre tahsilat yapamadığı için serbest meslek makbuzu düzenlemeyecek fakat 3065 sayılı kanunun 10. maddesine göre hizmetin bitişini takip eden ay içinde 10 yıllık hizmet bedelini katma değer vergisi beyannamesine yansıtmak zorunda kalacaktır. Bu da tahsil edilemeyen kazançların vergisini ödeme yükümlülüğü doğuracaktır. Anayasamız m. 73'e göre "herkes, kamu giderlerini karşılamak üzere, mali gücüne göre, vergi ödemekle yükümlüdür". 3065 sayılı Katma Değer Vergisi Kanununun 10. maddesinin Anayasanın 73. Maddesine aykırı olduğu açıktır. Örneğimizdeki 10 yıllık bir hizmetin, milyonlarca lira değerinde olması ihtimal dahilindedir. Bu 
meblağın KDV'si de yüzbinlerce lira tutabilir. Eğer bu hizmet bedeli tahsil edilemez ise serbest meslek erbabı "mali gücüne göre" vergi ödemiş olmayacaktır. Bu durum tahsil edemediği bedelin KDV sini ödemek zorunda kalan serbest meslek mensubunun mahvina neden olabilecektir. 3065 sayılı KDV Kanunu'nun 10. Maddesinin Anayasaya aykırı olduğu gerekçesiyle somut norm denetimi yöntemi ile Anayasa Mahkemesi tarafından iptal edilebilmesi mümkündür. Fakat bunun için, derdest olan benzer bir davada vergi mahkemesi hakiminin Anayasa aykırılık iddiası ile Anayasa Mahkemesine başvurması gerekmektedir (Any m. 152).

Vergi dava daireleri kurulunun bahse konu kararı 3065 sayılı KDV kanunun hali hazırdaki 10. maddesine uygundur. Fakat 213 sayılı VUK 236. ve 237. Maddelerine ve 193 Sayılı GVK nın 65. ila 67. maddelerine aykırılık teşkil etmektedir.

3065 sayılı KDV Kanunun 10. maddesinin " $\mathrm{c}$ " bendinde hizmet sözleşmelerinde bir kısım hizmetin ifa edilmesi durumunda KDV'nin doğacağından bahsedilmektedir. Fakat hizmet sözleşmelerinin tahsilat gerçekleştirmeden kısımlara bölünmesi mümkün değildir. Şöyle ki; bir avukatın önceden ne kadar süreceği kestirilemeyen ve yaklaşık üç/beş yıl sürebilecek bir davada, bu hizmeti kısımlara bölmesi teknik olarak mümkün değildir. Bir ceza davasında hizmet, süreç halinde devam etmektedir. Soruşturmaya ve kovuşturmaya yönelik evrak alış verişi, delil ikame edilmesi gibi faaliyetler devam ederken yargılamayı kısımlara bölmek mümkün değildir. Kısmi ifanın yapıldığını söyleyebilmek için muhakkak o ana kadar sunulan hizmetlerin bedeli de tahsil edilmiş olmalıdır. Tahsilat olmadan bu beş yıllık hizmeti "hangi andan itibaren yeni bir kısmi hizmet sayılmalıdır?" şeklinde sınıflandırmak mümkün değildir. Bu nedenle 3065 sayılı KDV kanununun " $\mathrm{c}$ " bendinde değişikliğe gidilmesi gerekmektedir. Bu kapsamda fıkra; "kısım kısım mal teslimi veya hizmet yapılması mutad olan veya bu hususlarda mutabık kalınan hallerde, her bir kısmın teslimi veya bir kısım hizmetin yapılmıș sayılması ancak tahsilatın gerçeklemiș olması kaydıyla meydana gelir" şeklinde değiştirilmesinin uygun olacağı değerlendirilmektedir. Şayet bu değişiklik yapılmayacak olursa her bir serbest meslek erbabının kendi mesleki kanunlarında değişiklik yapılması da akla gelebilir. Bu kapsamda örneğin; aylık, üç aylık gibi zaman periyotlarında tahsilat zorunluluğu getirilebilir. Fakat her bir meslek mevzuatında bu değişikliğin yapılması serbest meslek türlerinin fazlalığı da dikkate alındığında akıllıca olmayacaktır. Bu nedenle 3065 sayılı KDV kanunun 10. Maddesinin " $\mathrm{c}$ " bendinde "tahsilat yapma zorunluluğunun getirilmesi" bu konuda yaşanabilecek sorunları çözebilecektir. KDV Kanununda yapılacak bu değişiklik, maddenin VUK ve GVK ile uyumlu hale gelmesini sağlayacaktır.

KDV Kanunu'nun 10. Maddesinde yapılması istenen değişiklik gerçekleşene kadar Anayasaya aykırı olan bu maddenin mahkemeler tarafından uygulanması zorunludur. Bu süreç de KDV Kanunu'nun mahkemeler tarafından uygulanması hakkaniyete aykırı kararlar verilebilmesine yol açacaktır. Bu nedenle gördüğü bir dava esnasında kanun maddesini uygulamak zorunda kalan vergi mahkemesi hakimi, Anayasamızın 152'ncu maddesinde düzenlenmiş olan "somut norm denetimi" yöntemiyle, maddenin iptal edilmesini Anayasa Mahkemesinden isteyebilir. 


\section{KAYNAKÇA}

Çanakkale, Osman F. (2008). Serbest Meslek Kazançlarında Tahsilat Olmasa da KDV Doğar,

https://www.muhasebenet.net/makale osman $\% 20 \mathrm{f} \% 20$ canakkale serbest $\% 20$ meslekte\%20tahsil at \%20olmasa\%20da\%20kdv\%20dogar.html (Erişim Tarihi: 01. 03. 2021).

Danıştay Vergi Dava Daireleri Kurulu (14. 04. 2006 Tarih ve E: 2006/19, K: 2006/92 Sayılı Kararı www.sinerjimevzuat.com.tr) (Erişim Tarihi: 16. 09. 2019).

Danıştay 9. Daire (19. 02. 1998 Tarih ve E: 1997/402, K:1998/651 Sayılı Kararı) www.emsal.danistay.uyap.gov.tr, (Erişim Tarihi: 02. 03. 2019).

Denizli Vergi Dairesi Başkanlığı Mükellef Hizmetleri Grup Müdürlüğü, (20.07.2011 Tarih ve B.07.1.GİB.4.20.15.01-30-MUK-2010-54-203 Sayıl1 Mukteza (Özelge)), www.gib.gov.tr/node/90935), (Erişim Tarihi: 01. 03. 2019).

Milli Eğitim Bakanlığı, (2011), Muhasebe ve Finansman Fatura ve Fatura Yerine Geçen Belgeler, www.megep.meb.gov.tr/mte program modul/moduller pdf/fatura\%20ve\%20fatura $\% 20$ yerine\%20ge\%C3\%A7en\%20belgeler.pdf (Erişim Tarihi: 06.03.2019).

Serbest Meslek Kazancı Elde Eden Mükellefler İçin Vergi Rehberi, (2019), Yayın No. 301, S.1, www.gib.gov.tr/2019-gelir-vergisi-rehber-ve-brosurleri 06/03/2019

Yıldız, A. Murat (2015). Dönem Sonu İşlemlerinin Vergisel Boyutu, Ankara SMMM Odası Yayın No: 100, Ankara.

www.vergidosyasi.com/2017/09/21/vergilemede-tahakkuk-ve-tahsil-esasi/ (Erişim Tarihi: 06.03.2019).

193 Sayılı Gelir Vergisi Kanunu(www.mevzuat.gov.tr/MevzuatMetin/1.4.193.pdf) (Erişim Tarihi: 22. 02. 2019).

213 Sayılı Vergi Usul Kanunu (www.mevzuat.gov.tr/MevzuatMetin/1.4.213.pdf) (Erişim Tarihi: 22. 02. 2019).

3065 Sayılı Katma Değer Vergisi Kanunu (www.mevzuat.gov.tr/MevzuatMetin/1.5.3065.doc) (Erişim Tarihi: 22. 02. 2019). 